\title{
2011 年日本地理学会秋季学術大会プログラム
}

2011 年日本地理学会秋季学術大会を, 大分大学において, 下記の要領で実施いたします.

\section{1. 大会日程}

9 月 23 日 (金) 10 時 00 分 11 時 30 分 11 時 30 分 12 時 30 分 13 時 00 分 17 時 20 分 13 時 00 分 17 時 30 分

13 時 00 分 15 時 00 分

18 時 00 分 20 時 00 分 9 月 24 日（土）

9 時 00 分 12 時 00 分 9 時 00 分 14 時 00 分 9 時 00 分 12 時 00 分

9 時 00 分 12 時 00 分

13 時 00 分 16 時 40 分

13 時 00 分 16 時 30 分

13 時 00 分 17 時 00 分

13 時 00 分 17 時 00 分

9 月 25 日（日） 8 時 30 分 18 時 00 分 9 時 00 分 16 時 30 分 9 時 00 分 16 時 00 分

9 月 26 日（月） 8 時 30 分〜18 時 00 分
代議員会（教育福祉科学部棟 100 号教室）

科学研究費補助金説明会（教育福祉科学部棟 100 号教室）

口頭発表

ポスター発表

(説明・討論は 23 日（金） 17 時から 17 時 30 分までと 24 日（土） 12 時から 12 時 30 分までの間に行います)

第 20 回地理教育公開講座 持続可能な社会と地理教育実 践—ESD カリキュラムと教材・授業の開発—（第 1 会場）

懇親会 (大分大学生協食堂)

口頭発表

ポスター発表

シンポジウム S11 近世期の測量絵図と歴史 GIS

(第 5 会場)

シンポジウムS12 アジアにおける持続可能な土地利用 の形成に向けて（第 6 会場）

シンポジウムS13 九州のジオパークの現状とこれから

(第 1 会場)

シンポジウム S14 フィールドワークの安全安心と支援 (第 3 会場)

シンポジウムS15「軍港都市」の近現代——社会・文 化・経済の連続と非連続——(第 2 会場 $)$

研究グループ集会

巡検第 1 班

巡検第 2 班

巡検第 3 班

巡検第 1 班

\section{2. 大会会場}

大分大学 干 870-1192 大分県大分市旦野原 700

土居晴洋 (教育福祉科学部) 電話 097-554-7549 e-mail: hdoi@oita-u.ac.jp

\section{3. 会場への交通案内}

1）大分空港からのアクセス 大分空港アクセスバス（エアライナー）に乗車し, 終点の「大分駅前」で下車 します. 所要時間は 60 分, 運賃は 1,500 円です. その後, JR 豊肥線普通列車を御利用下さい.

2) JR 線によるアクセス JR 大分駅へは，JR 日豊線では，小倉駅から特急列車で 1 時間 20 分〜30 分，宮崎 駅から 4 時間 30 分程度です. JR 久大線では, 久留米駅から特急列車で 2 時間 30 分程度, JR 豊肥線では, 熊本 駅から特急列車で 2 時間 50 分程度です。 その後, JR 豊肥線普通列車を御利用下さい.

3） JR 大分駅からのアクセス JR 豊肥線普通列車に乗車し, 「大分大学前」駅で下車します. 普通列車は, 日 中は 1 時間に 2 本程度運行しており,「大分」-「大分大学前」駅間の所要時間は 12 分程度, 運賃は 240 円です. 
4）大分市中心部からのバスのアクセス バス乗車場（大分バス）「大分駅前」もしくは「トキハデパート前 (1)のりば」から「大南団地・高江ニュータウン」行きに乗車し，「大分大学正門」で下車します．所要時間は 30 分，運賃は 360 円です。

$\mathrm{JR}$ 豊肥線で大分大学前駅に到着しましたら，駅正面の横断歩道を渡ると，キャンパス内へつづく歩道があります。 大会会場まで㧍よそ10 分です。 バスで「大分大学正門」で下車した場合は，正門から大会会場まで拈よそ 5 分です.

大分大学ホームページに大分大学へのアクセスの案内拉よびキャンパスマップがありますので御活用下さい. なお，大会会場は「旦野原（だんのはる）キャンパス」です。「挾間（はさま）キャンパス」ではありませんの で，御注意下さい.
受 付 教育福祉科学部第 1 会議室 1 階
第 1 会場 教育福祉科学部棟 100 号教室 1 階
第 2 会場 教育福祉科学部棟 200 号教室 2 階
$\begin{array}{lll}\text { 第 } 5 \text { 会場 教養教育棟 } 14 \text { 号教室 } & 1 \text { 階 } \\ \text { 第 } 6 \text { 会場 教養教育棟 } 32 \text { 号教室 } & 3 \text { 階 }\end{array}$
第 7 会場 教育福祉科学部棟 204 号教室 2 階
第 3 会場 教育福祉科学部棟 300 号教室 3 階
書籍展示 教育福祉科学部第 2 会議室, 改革推進室 1 階
第 4 会場 教養教育棟第 2 大講義室 1 階
懇 親 会 大分大学生協食堂

\section{4. 大会参加の諸費用}

$$
\begin{array}{cl}
\text { 大会参加費 : 正会員 } & 2,000 \text { 円 } \\
\text { 正会員 (院生 ·学部学生) } & 1,500 \text { 円 } \\
\text { 一 般 (非会員) } & 2,500 \text { 円 (高校生以下, 無料) }
\end{array}
$$

懇親会参加費 5,000 円（院生・学生 3,000 円）

発表要旨集 2,500 円 会場受付で販売します.

大会参加費と懇親会会費は当日会場で受け付けますが，それらの領収証発行は省略し，参加証（名札）の発 行をもって代えます，特に領収証を必要とされる方は，受付手続の際にお申し出下さい.

\section{5. 会場周辺の宿泊施設について}

大分市内には JR 大分駅周辺などに多くの宿泊施設があります。混み合うことが予想されますので，㧍早目の 手配を扔願いします。な㧍，別府市内にも多くの宿泊施設があります．JR 別府駅から JR 大分駅までの所要時間 は, 普通列車で 15 分です.

\section{6. 食事の案内}

大会期間中（23 日，24 日）の昼食については，学内の生協食堂が営業しています．なお，営業時間は両日と も, 11 時 30 分から 13 時までです.

\section{7. 巡検の集合時間・場所}

第 1 班「九州阿蘇の自然と文化——阿蘇ジオパークと世界遺産候補をめぐる—」(1 泊)

9 月 25 日（日） 8 時 30 分 JR 大分駅南口

第 2 班「北九州市における都市空間の変容—一小倉都心部・八幡東区東田地区を中心に一—」（日州り）

9 月 25 日（日） 9 時 JR 八幡駅改札前

第 3 班「別府湾を巡る自然と観光・文化」（日帰り）

9 月 25 日（日） 9 時 JR 大分駅

\section{8. 口頭発表について}

人名の*印は口頭発表者を示します。発表時間は討論・交替時間を含めて 19 分とし，1 鈴 12 分，2 鈴 15 分 (発表終了)，終鈴 19 分（討論終了）となります。発表時間枠が固定されていますので，発表者㧍よび座長は発 表時間を厳守して下さい.

な㧍，液晶プロジェクターの使用者は，Windows 版の PowerPoint2003 で正常に表示されることを確認した ファイルを，USBメモリー（Windows で読み込めるフォーマット）に保存して御持参下さい．な扔，事前に各 自で必ずウイルスチェックを行って下さい。各自発表のセッション開始 20 分前までに各会場まで上記メディア を持参し，担当の者に渡して下さい。 


\section{9. ポスター発表について}

ポスター発表は，9月 23 日（金）13 時より 17 時 30 分までと，24 日（土） 9 時より 14 時まで，第 7 会場で 行います。発表者による説明・討論は 9 月 23 日（金）17 時 17 時 30 分もしくは 9 月 24 日（土） 12 時 12 時 30 分までの間に行われますので, 多くの会員の参加を希望します.

ポスター発表者は，9月 23 日（金） 13 時までに，第 7 会場の指定された場所にポスターを揭示して下さい. ポスターのサイズは幅 $90 \mathrm{~cm} \times$ 高さ $170 \mathrm{~cm}$ です. 当日の揭示の方法は会場係の指示に従って下さい.

発表者は 9 月 23 日（金） 17 時 17 時 30 分と 9 月 24 日（土） 12 時 12 時 30 分の間に少なくとも 20 分間は 各自の展示の場所で，質疑・討論に対応して下さい。説明・討論時間は上記時間内でなるべく長く取ることを 希望します。ポスターは 9 月 24 日（土） 14 時〜15 時の間に各自の責任で片づけて下さい.

\section{0. 出張依頼状・発表要旨集について}

（1）出張依頼状の必要な方は，1．出張期間，2．依頼状提出先，3．依頼状送付（返信）先を明記し，切手を 貼付した返信用封筒を同封の上，学会事務局へ抒申し込み下さい.

（2）定期購読をされている方で発表要旨集が 9 月 16 日（金）までに未着の場合は，学会事務局へお申し出下 さい.

\section{1. 地理教育公開講座}

地理教育公開講座委員会主催 第 20 回地理教育公開講座

日 時 9 月 23 日 (金) 13 時 15 時

会 場 第 1 会場

テーマ 持続可能な社会と地理教育実践——ESD カリキュラムと教材・授業の開発——

中山修一（広島大学名誉教授，広島経済大学名誉教授）：地理 ESD カリキュラムと教材開発の目標・ 内容・方法

和田文雄 (広島大学附属福山中・高等学校元教諭) : 中・高等学校における ESD としての地理実践に向けて —グローバル化の視点を踏まえて——

問合せ先 永田忠道（大分大） e-mail: tnagata@oita-u.ac.jp

電話・FAX 097-554-7546

\section{2. 科学研究費補助金説明会について}

科学研究費補助金説明会を開催いたします.ふるって御参加下さい.

日 時 9 月 23 日 (金) 11 時 30 分 12 時 30 分

会 場 教育福祉科学部棟 100 号教室 (1 階)

吉野 明 (日本学術振興会研究助成第一課長) : 科研費の最近の動向

\section{3. 地域調查士相談室の開設について}

資格専門委員会では地域調査士相談室を開設します。科目認定申請を予定する大学関係者対象の事前相談の 場として御活用下さい.

日 時 9 月 23 日 (金) 13 時 17 時

場 所 教育福祉科学部棟 202 号教室 (2 階)

\section{4. 大 会役員}

千田 昇 (委員長), 大吕興平 (会計), 土居晴洋 (会場・総務), 宮町良広 (懇親会), 永田忠道 (受付) 


\section{第1日目 9月23日（金）午後}

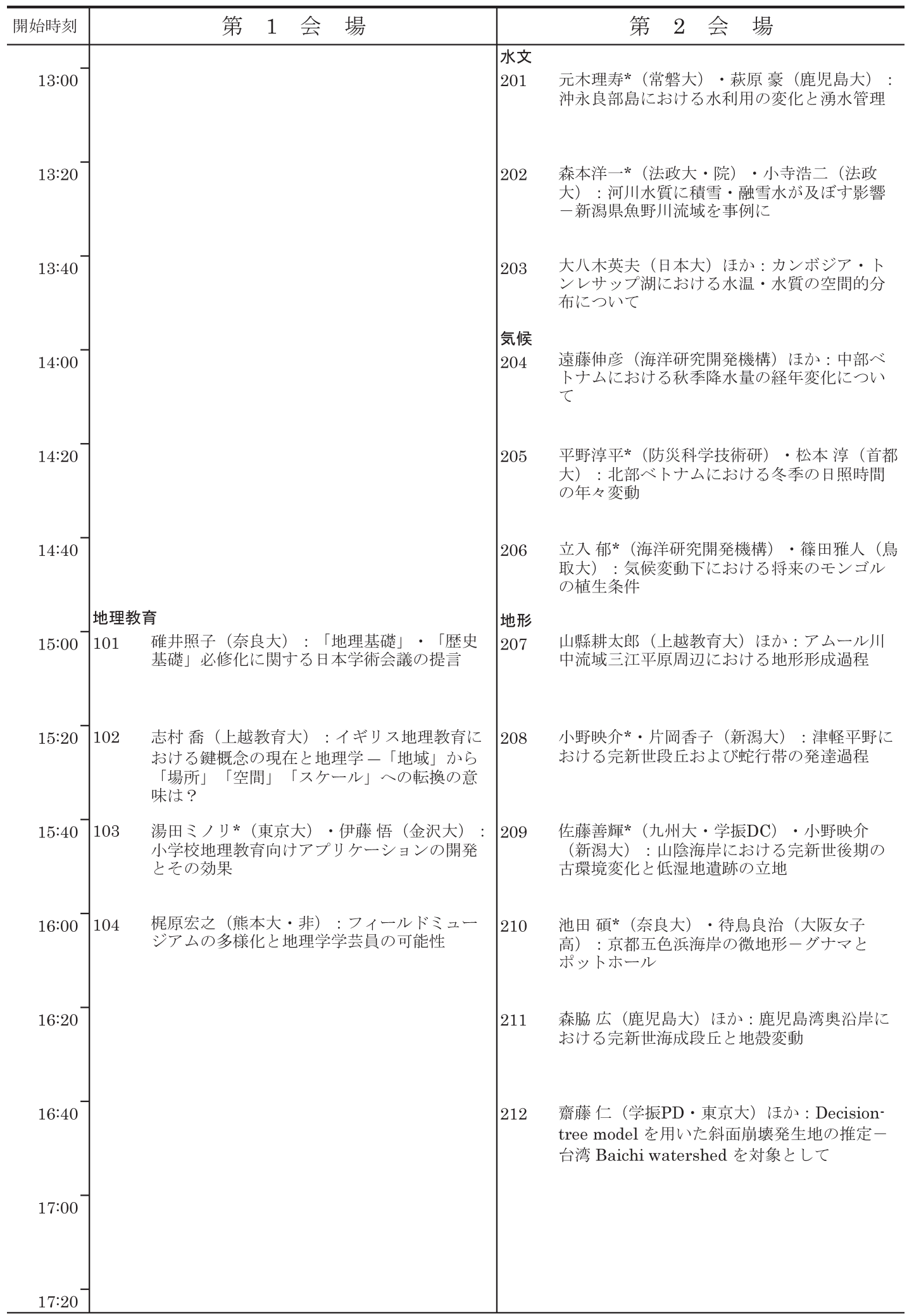


第1日目 9月 23日（金）午後

\begin{tabular}{|c|c|}
\hline 観光 & \\
\hline 301 & $\begin{array}{l}\text { 金玉実（筑波大）：北海道道東における中国人 } \\
\text { の観光行動空間の成立過程 }\end{array}$ \\
\hline 302 & $\begin{array}{l}\text { 池口功晃（別府大短期大学部）：観光の嗜好性 } \\
\text { に関寸るコンジョ学生と外 } \\
\text { 国人留学生の比較 }\end{array}$ \\
\hline 303 & $\begin{array}{l}\text { 太田 孝（横浜市立大・院）：昭和前半期の日 } \\
\text { 本人の行楽・旅行に関する意識形成に与えた } \\
\text { 修学旅行の影響 }\end{array}$ \\
\hline 304 & $\begin{array}{l}\text { 杉本興運（首都大・学振DC）：ハイキング利 } \\
\text { 用者心理の多次元性と時間変化 }\end{array}$ \\
\hline 305 & $\begin{array}{l}\text { 中岡裕章（日本大・院）：江の島における日帰 } \\
\text { り観光の実態 }\end{array}$ \\
\hline
\end{tabular}

歴史

306

307

文化

308 曽我とも子 (岡山大・院) : 㧛島管絃祭の期日 に関する陰陽五行思想からの考察

中島弘二（金沢大）：大分県日出生台演習場 における軍事化と抵抗

渡邊英明（大阪大・院）：日記史料にみる江 戸時代後期の定期市と人々の関わり リーにみる「八重山ミンサー」の変容一石垣 市におけるA氏と家族のライフヒストリーを事 例に

310 細井將右（地図情報研）：明治初期ジュルダン らによる豊後水道の地図ほかと伊能図など 図』のGISデータベース構築と近代京都の都市 的土地利用

赤沢正晃（日本大・院）：地図作製のデジタ ル化にともなう簡易GPSの改善と利用法

\begin{tabular}{|ll|l} 
& 第 4 会 場 & 開始時刻 \\
\hline 東日本大震災 & 海津正倫 (奈良大) & \\
401 & 震に伴う仙台・石巻平野の津波の流動と土平洋沖地 & 13:00 \\
& 件 & \\
& &
\end{tabular}

天笠雅章（筑波大）：東北地方太平洋沖地震後 の津波に起因した岩手県下閉伊郡山田町田の浜 地区における火災事例研究

青山雅史*（日本地図センター）・小山拓志 （明治大・院）：2011年東北地方太平洋沖地 $13: 20$ 震による利根川下流低地の液状化被害域にお ける土地履歴の特徴

村山良之（山形大）ほか：造成宅地における地 震による建物被害パタンの提案

尾方隆幸（琉球大）：原発事故による阿武隈高 地の放射能污染一流域ごとの線量分布

地の放射能污染一流域ことの線量分布

高木 亨 (地域開発研) ほか: 福島第一原子力 発電所事故によるいわき市川前町高部地区の放 射能污染の状況と住民生活

関根良平（東北大）ほか：東日本大震災以降の 福島県会津地方における食料生産・流通・消費 一主に野菜と乳製品に注目して

佐々木 緑 (広島修道大) ほか: 東日本大震災 15:20 被災地: 岩手県山田町における住民の買い物環 境と食品スーパーの対応

土屋 純（宮城学院女子大）：東日本大震災に よる東北地方の流通システムへの影響一食品 スーパーを事例として

中村 努（東京大・学術研究員）：医薬品供給 体制にお活る安全性と效率性一東日本大震災を 例に

久保倫子 (学振PD・明治大) ほか：東日本大 震災時における住民の行動一茨城県日立市の 事例

岩船昌起（志學館大）：新燃岳周辺地域におけ る「噴火」に対寸る危機管理一人間の体力を考 慮した避難体制の試み 本大震災と原子力災害に伴う住民・自治体の 移転と学校教育一福島県いわき市における教 育復興支援に向けての現状調査 


\section{第1日目 9月 23日（金）午後}

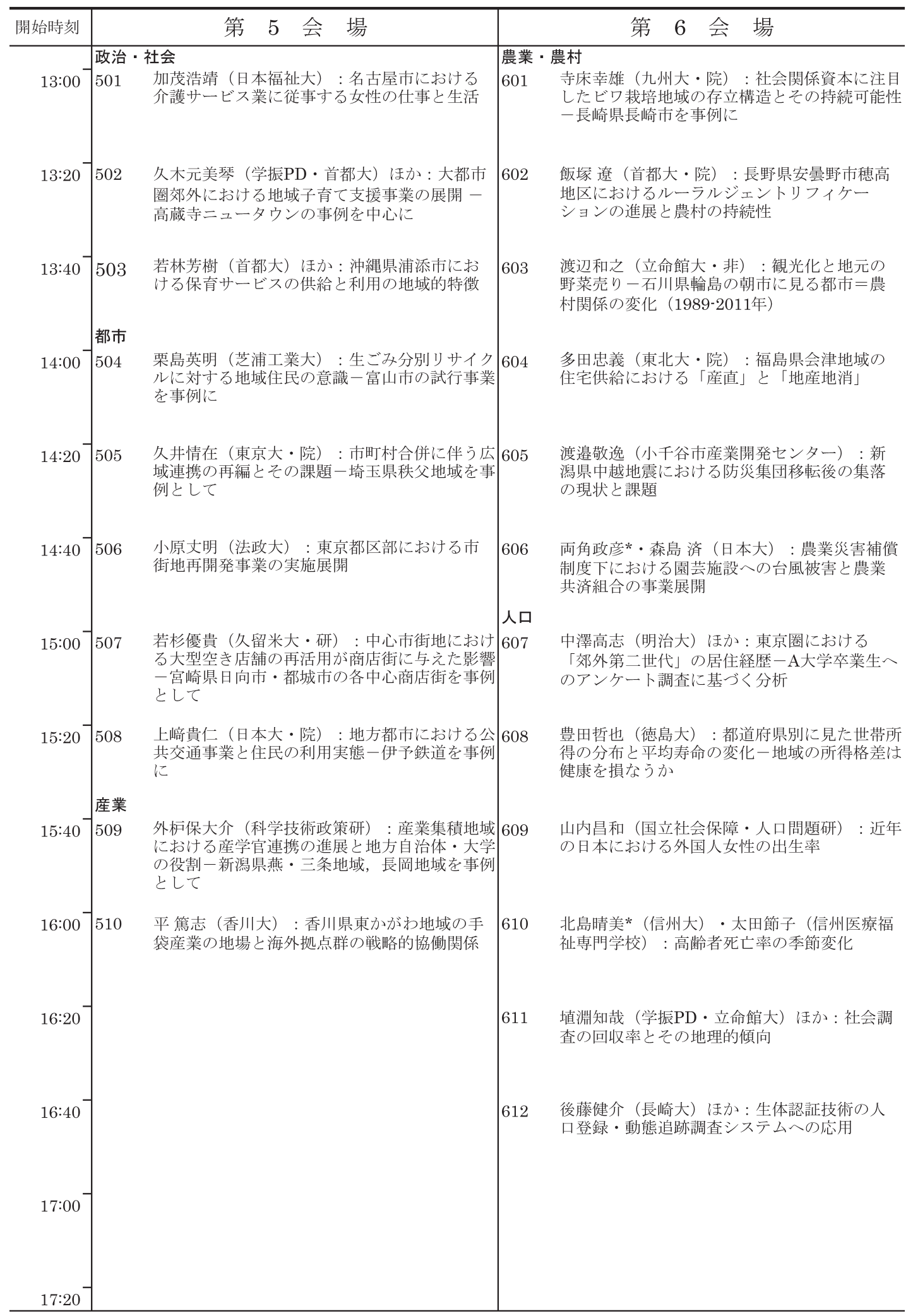




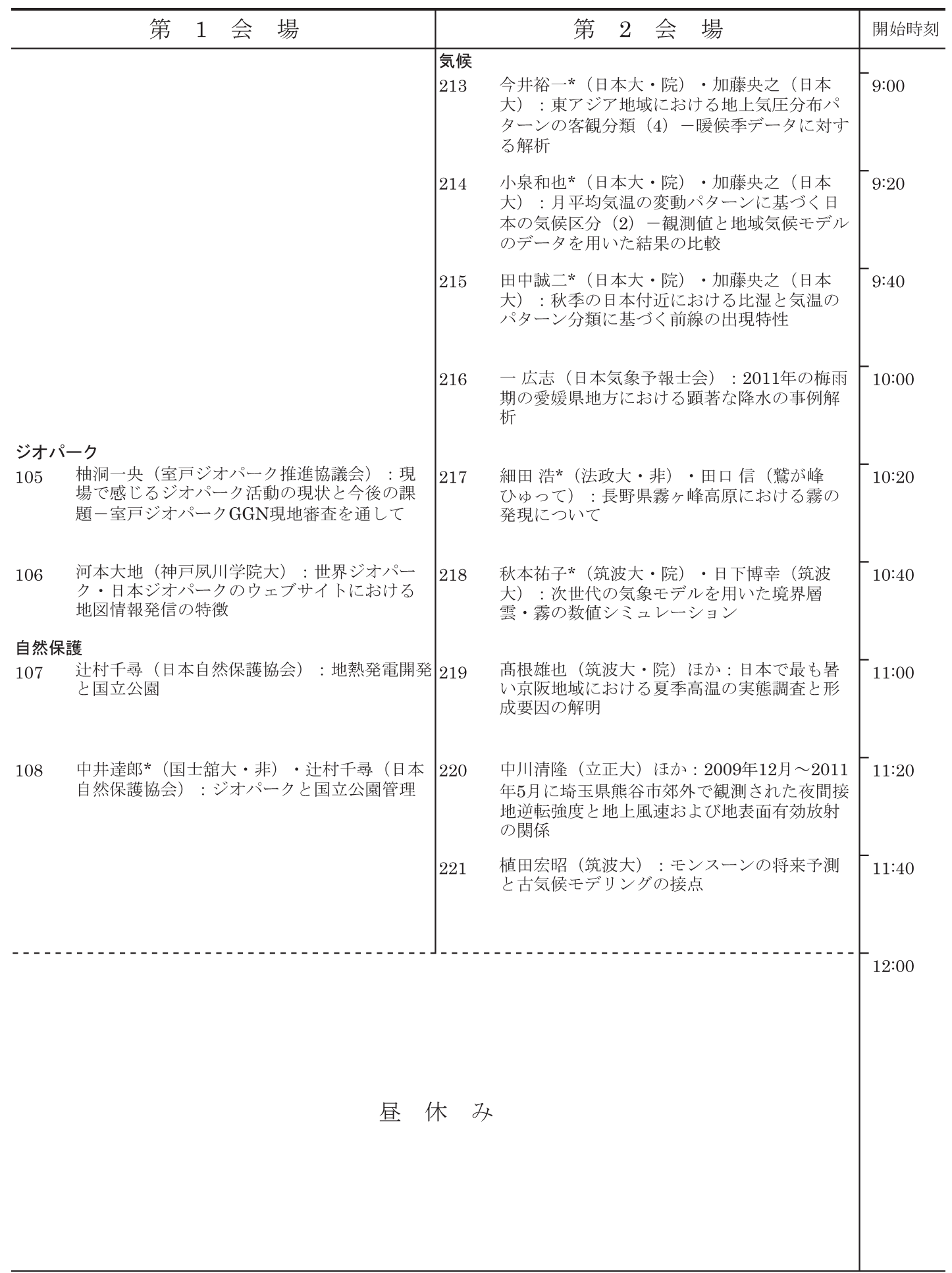


第2日目 9月 24日（土）午前

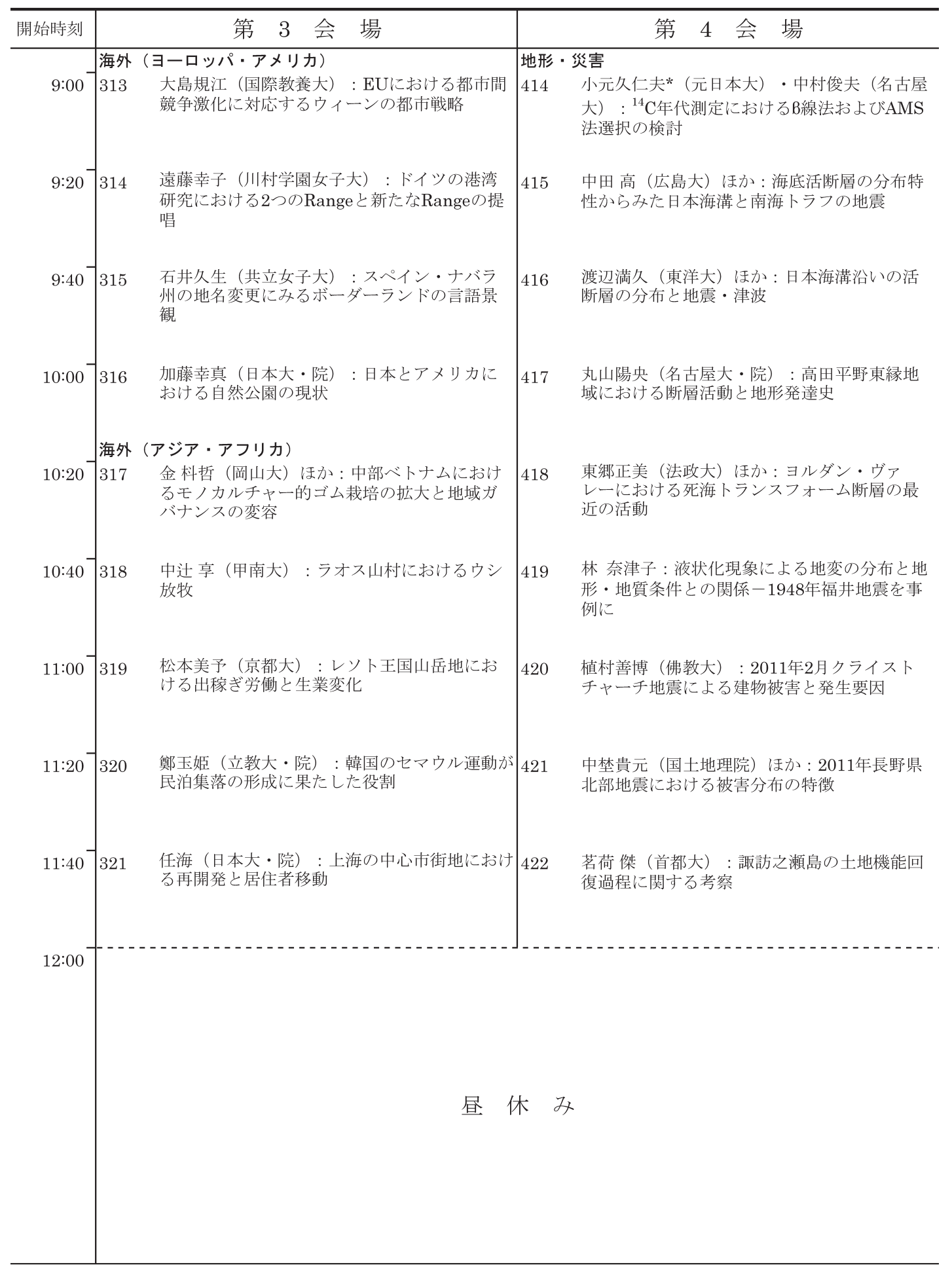


第2日目 9月24日（土）午前

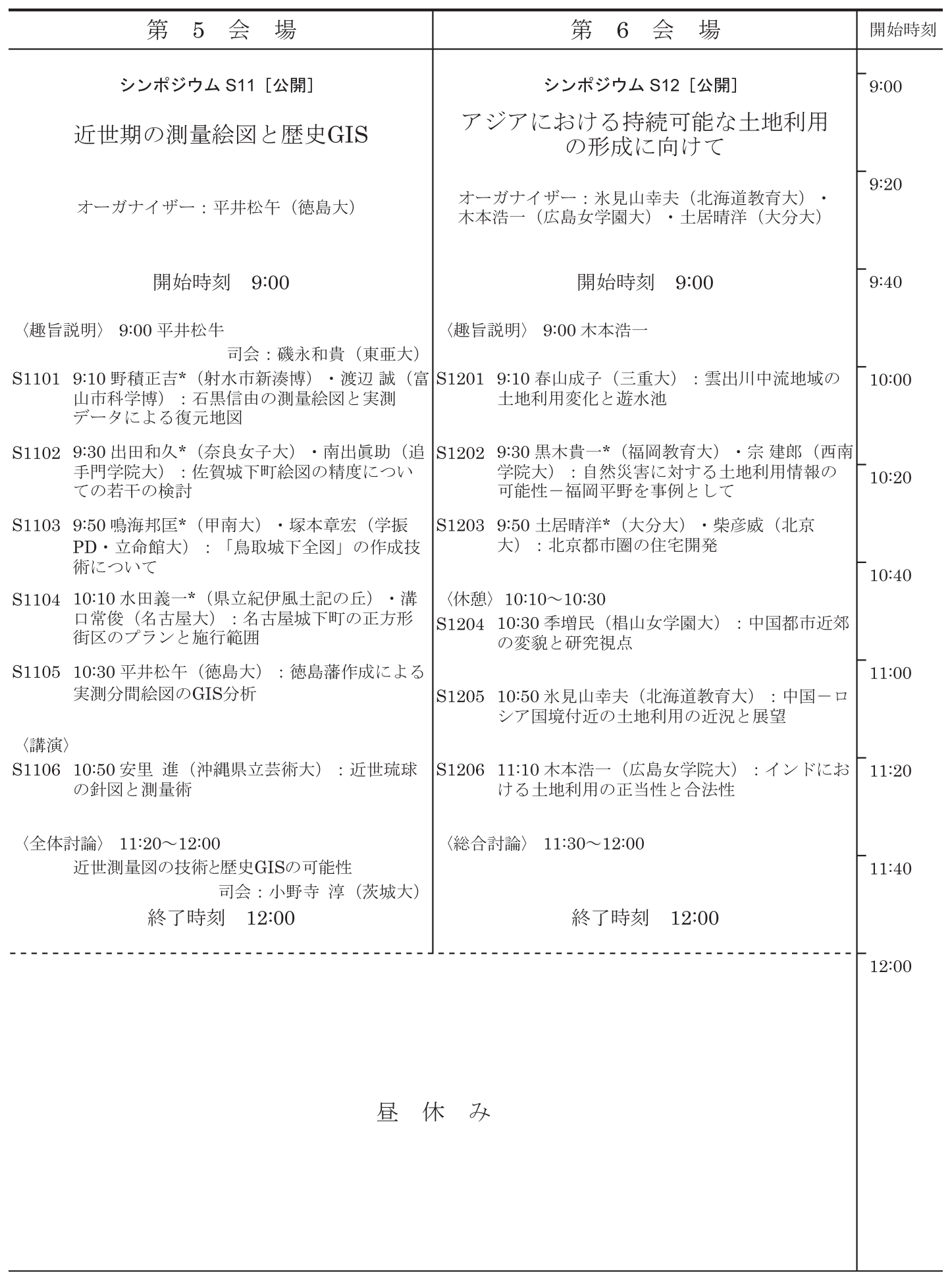


第2日目 9月 24日（土）午後

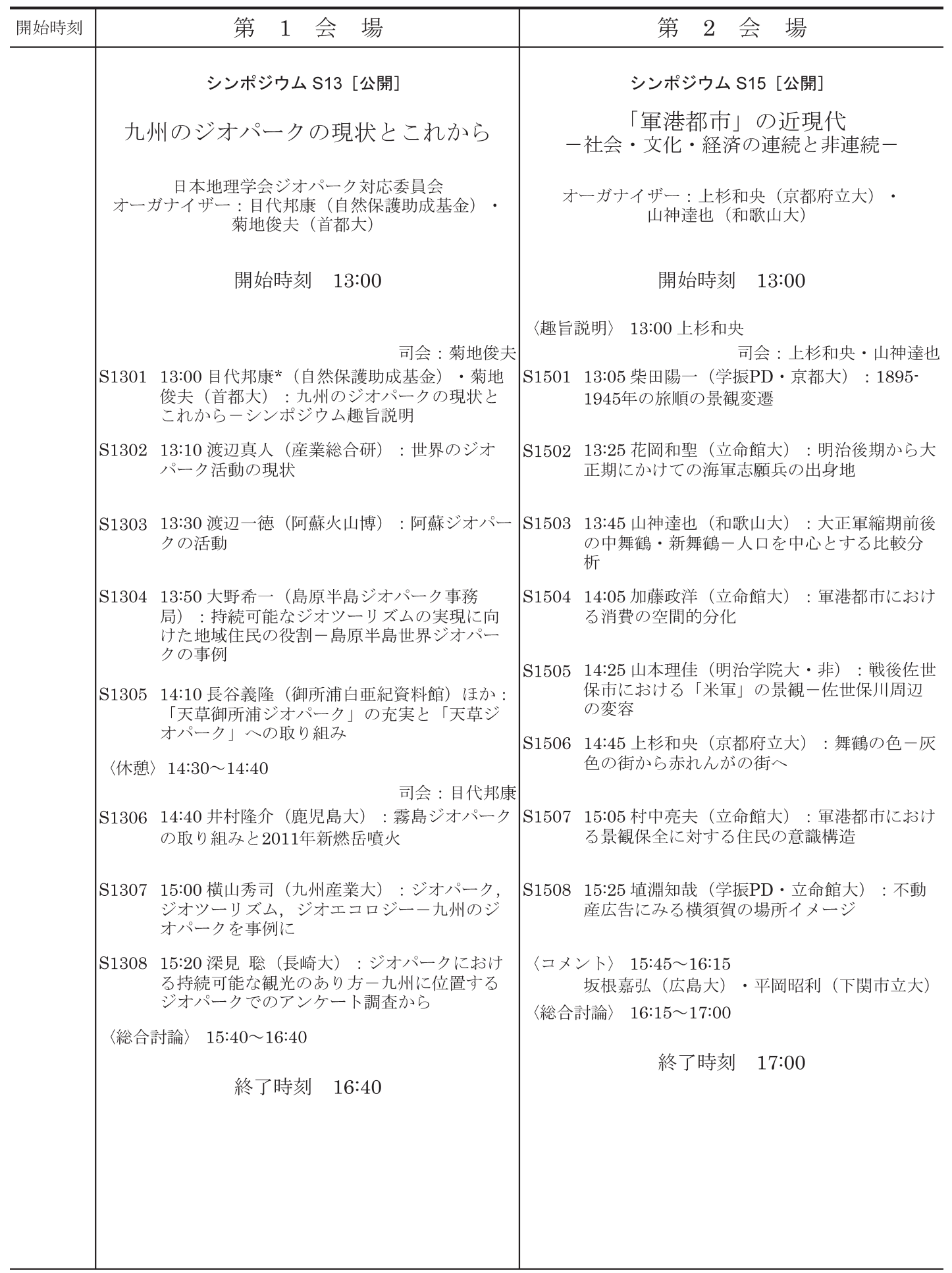




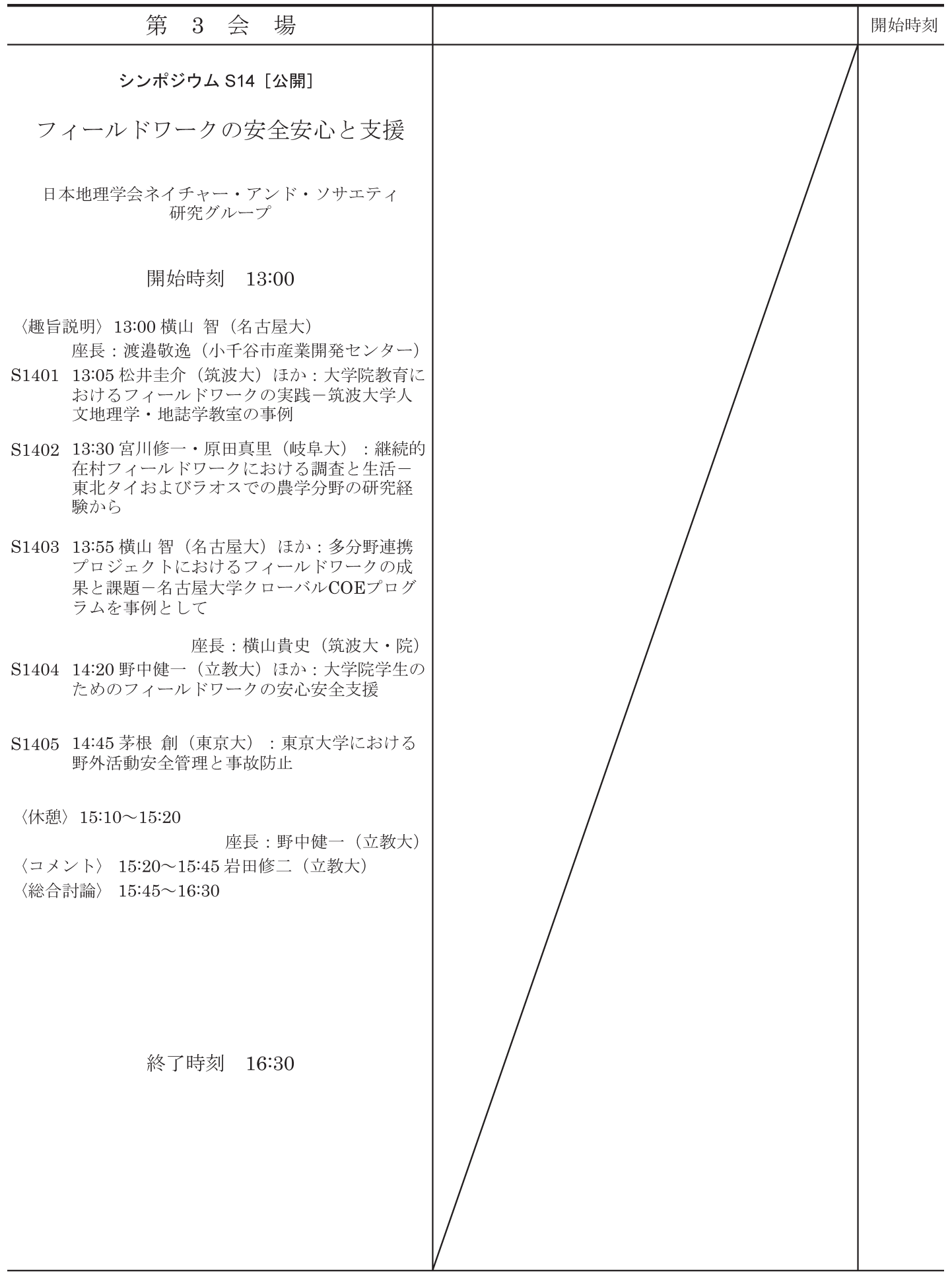




\section{第 7 会 場}

ポスター発表

ポスター発表は，9月23日（金）13時〜17時30分と9月24日（土） 9時〜14時，第7会場で行われます。 発表者による説明は，9月23日（金）17時～17時30分もしくは9月24日（金）12時～12時30分に行いますの で，多くの会員の参加を希望します。

P701 佐々木史郎（宇都宮大）：韓国南海岸島嶼地 域の複列型閒取りの民家をめぐる問題につい $\tau$

P702

中川恵理子（東京大・院）：生鮮野菜卸売価 格の空間分布に関する一考察

P703 梶田真（東京大）：1970年代後半以降の国際 建設業の動態－ENR誌Top International Contractors 調査の分析を中心に

P704 荒木一視（山口大）ほか：アジア太平洋地域 における第3次フードレジーム

P705林 玩也（岐阜大）：クラブ制リンゴ「ピンク レディー」の特性一国際ピンクレディー連 盟・通常総会2010をもとに

P706 吉田国光（熊本大）ほか：天草市宫地岳町にお ける農地維持の諸相一個別農家と集落営農組織 の役割

P707＼cjkstart林 紀代美（金沢大）：食材の普及と流通・消 費にみられる地域性一沖縄の人々はサンマ・开 ケをどう受け入れてきたか?

P708 齋藤譲司（筑波大・院）：近代化遺産の保存活 用の課題一長野県須坂市を事例に

P709 山田周二（大阪教育大）：スーパーマーケッ 卜で販売されている味噌にみられる地域性と その地理教材としての価值

$\mathrm{P} 710$

水野惠司（大阪教育大）：メキシコの小中学 校地理教育
P711 HARUYAMA Shigeko *(Mie Univ.) and Khin Khin Wai (Yangon Univ.): Recent land use change of Hmawbi Township in Myanmar.

P712 御園理紗（東京工業大・院）：歴史的町並み における夜間景観形成の可能性と課題一埼玉 県川越市「川越一番街」を事例として

P713 坪本裕之（首都大）ほか：東京都中央区日本 橋地区における近年のマンション開発と人口 変化

P714 桐村 喬（学振PD - 立命館大）：長期的な小地 域人口の分布の変化からみた都市の居住地域 構造の変遷 -1908 年から 2005 年の東京の事例

P715 AKIMOTO Natsumi (Grad. Student, Univ. of Tokyo) : Accessibility to the life-necessaries facilities under the different terrain conditions: The case studies of Toyama and Tohkamachi cities.

青木和人* (宇治市役所) ・武田幸司（パス コ）：固定資産税路線価における街路系統性 の分類方法

P717 佐藤裕哉（広島大）ほか：地理情報システム を用いた広島原爆被爆者位置情報の高精度化

黒田圭介（西南学院大・非）ほか：那珂川中 流域におけるLANDSATデータバンド4画像合 成空中写真を用いた土地被覆分類

野中健一（立教大）ほか：スマートフォンを 利用したWeb-GIS/GPSによるフィールドワー クサポートシステム

森脇広（鹿児島大）ほか: 南太平洋, クック 諸島における海岸平野とサンゴ礁の ${ }^{14} \mathrm{C}$ 年代 
ポスター発表は，9月23日（金）13時〜17時30分と9月 24 日（土） 9時〜14時，第7会場で行われます。 発表者による説明は，9月 23 日（金） 17時～17時30分もしくは9月 24 日（金） 12時～12時30分に行いますの で，多くの会員の参加を希望します。

P721 高岡貞夫* (専修大) ・ スワンソン， F. J. (米国農務省森林局) : カスケード山脈西斜 面における草原・低木林と地形一航空写真と 航空レーザ測量データを併用した分布図の作 成

P722 磯望（西南学院大）ほか：2011年新然岳噴火 降下テフラ層の特徵とその変化

P723 吉田英嗣（関東学院大）：那須火山，観音川 岩屑なだれの流れ山の縦断分布特性

P724山縣耕太郎（上越教育大）ほか：カムチャツ カ半島中央部エッソ周辺の高山帯における土 壤生成開始条件

P725 熊木洋太 (専修大) ほか：旧版地形図を用い た大正関東地震前の三浦半島南部の海岸線を 復元する試み

P726 黒木貴一（福岡教育大）ほか: 那珂川中流域 におけるレーザーデータを用いた氾濫原の地 域区分

P727 後藤健介（長崎大）ほか：水害汇濫域におけ る衛星データおよび標高データを用いた環境 特性解析

P728

大庭雅道（電力中央研）ほか：自己組織化 マップを用いた日本域の夏季における異常気 象パターンの抽出

P729 田上善夫（富山大）：日本列島における強風 出現の地域的差異

P730 浜田 崇* ・田中博春（長野県環境保全研）：諏 訪湖における結水日数の経年変化
|P731 丸本美紀（お茶の水女子大・院）ほか：明治 末期〜昭和初期の気象資料による奈良の水収 支気候と年候

田代崇（日本大・院）ほか：フィリピン・ル ソン島中央平原パイタン湖における湖底堆積 物の粒度変動

P733 小荒井 衛・中埜貴元*（国土地理院）ほか：東 北地方太平洋沖地震の宮城県津波浸水域の土 地利用と地形の特徴

P734 平野信一（東北大）ほか：仙台平野における 平成23年 (2011年) 東北地方太平洋沖地震の 津波の実態

P735 青山雅史*（日本地図センター）・小山拓志 (明治大・院）：2011年東北地方太平洋沖地 震により生じた利根川下流低地における液状 化被害の分布図

P736 小山拓志*（明治大・院）・青山雅史（日本地 図センター) : 茨城県潮来市および神栖市に おける液状化被害分布と土地履歴との関係

P737 近藤昭彦（千葉大）ほか: 福島第一原発事故 によって拡散した放射性物質に起因寸る空間 線量率の分布の特性

P738 志村喬（上越教育大）ほか：東日本大震災に よる学校被災概要と地理（社会科）教材支援 希望一岩手県・宮城県・福島県における緊急 実態調査の報告 
15. 口頭発表座長表

\begin{tabular}{|c|c|c|c|c|}
\hline & \multicolumn{2}{|c|}{9 月 23 日（土）午後 } & \multicolumn{2}{|c|}{9 月 24 日（日）午前 } \\
\hline 第 1 会場 & $101 \sim 104$ & 井田仁康 & $105 \sim 108$ & 目代邦康 \\
\hline 第 2 会場 & $\begin{array}{l}201 \sim 203 \\
204 \sim 206 \\
207 \sim 209 \\
210 \sim 212\end{array}$ & $\begin{array}{l}\text { 沼尻治樹 } \\
\text { 浜田 崇 } \\
\text { 齋藤 仁 } \\
\text { 小野映介 }\end{array}$ & $\begin{array}{l}213 \sim 215 \\
216 \sim 218 \\
219 \sim 221\end{array}$ & $\begin{array}{l}\text { 中川清隆 } \\
\text { 植田宏昭 } \\
\text { 平野淳平 }\end{array}$ \\
\hline 第 3 会場 & $\begin{array}{l}301 \sim 303 \\
304 \sim 305 \\
306 \sim 307 \\
308 \sim 309 \\
310 \sim 312\end{array}$ & $\begin{array}{l}\text { 鈴木晃志郎 } \\
\text { 河本大地 } \\
\text { 山根 拓 } \\
\text { 湯澤規子 } \\
\text { 島津俊之 }\end{array}$ & $\begin{array}{l}313 \sim 316 \\
317 \sim 319 \\
320 \sim 321\end{array}$ & $\begin{array}{l}\text { 山本健兒 } \\
\text { 横山 智 } \\
\text { 金 枓哲 }\end{array}$ \\
\hline 第 4 会場 & $\begin{array}{l}401 \sim 403 \\
404 \sim 406 \\
407 \sim 410 \\
411 \sim 413\end{array}$ & $\begin{array}{l}\text { 村山良之 } \\
\text { 近藤昭彦 } \\
\text { 荒一視 } \\
\text { 岩間信之 }\end{array}$ & $\begin{array}{l}414 \sim 416 \\
417 \sim 419 \\
420 \sim 422\end{array}$ & $\begin{array}{l}\text { 東郷正美 } \\
\text { 中田 高 } \\
\text { 渡辺満久 }\end{array}$ \\
\hline 第 5 会場 & $\begin{array}{l}501 \sim 503 \\
504 \sim 506 \\
507 \sim 510\end{array}$ & $\begin{array}{l}\text { 中澤高志 } \\
\text { 高木彰彦 } \\
\text { 鹿嶋＼cjkstart洋 }\end{array}$ & & \\
\hline 第 6 会場 & $\begin{array}{l}601 \sim 602 \\
603 \sim 604 \\
605 \sim 606 \\
607 \sim 608 \\
609 \sim 610 \\
611 \sim 612\end{array}$ & $\begin{array}{l}\text { 片岡義晴 } \\
\text { 中川秀一 } \\
\text { 川久保篤志 } \\
\text { 山内昌和 } \\
\text { 山神達也 } \\
\text { 梶田 真 }\end{array}$ & & \\
\hline
\end{tabular}


1. 日時および会場 9 月 24 日（土）. 会場はグループ名の後に示す.

2. 集会㧍よび話題提供

\section{$\cdot 13$ 時 15 時開催}

エスニック地理学研究グループ (教育福祉科学部 202)

小田隆史（搒の水女子大・学振 PD）：サンフランシスコ日本町の参加型再生計画策定にみる「エスニシ ティ」と合意形成

吉田道代 (摂南大) : 地理学に扔ける難民研究の動向— 2000 年代を中心に

情報地理研究グループ (教育福祉科学部 203)

山本健太 (九州国際大) : 地方におけるアニメーション産業の動向——沖縄県 M プロジェクトの報告

IGU 情報地理コミッション・アテネ会議報告

科研費研究の推進状況について

農業・農村の地理学研究グループ（教育福祉科学部 301）

離島地域研究グループ (教育福祉科学部 302)

堀本雅章（法政大・沖縄文化研究所）：架橋に対する住民意識——沖縄県座間味村慶留間島の事例

宮内久光（琉球大）：島嶼空間の脆弱性概念について

地図・絵図資料の歴史 GIS 研究グループ（教育福祉科学部 303）

礒永和貴 (東巠大) ・鳴海邦匡（甲南大）：熊本県立図書館蔵池部長十郎・啓太作成の測量分間絵図

意見交換：近世実測絵図をめぐる諸問題

今後の研究グループの活動計画について

産業経済の地理学研究グループ（教育福祉科学部 304)

小柳真二 (九州大・院) : 産学連携の空間性に関する分析枠組みの検討

加藤幸治 (国士舘大) :「日本の産業地図・2005」再考

都市地理学研究グループ (教育福祉科学部 404)

- 15 時 17 時開催

ジェンダーと空間/場所研究グループ（教育福祉科学部 202）

関村オリエ (群馬県立女子大)：2010 年 IGU イスラエル地域大会報告

村田陽平（京都大）：日本に扔ける「均等法」と職場の変容——外資系企業管理職の国際調査から—

現代南アジア研究グループ (教育福祉科学部 203)

少子高齢化と地域問題研究グループ（教育福祉科学部 301）

中條曉仁（静岡大）：静岡県中山間地域に抢ける集落の動向と地域住民の対応

近代日本の地域形成研究グループ（教育福祉科学部 303）

国際経済・経営地理学研究グループ (教育福祉科学部 304)

阿部康久（九州大）：中国大連に進出した日本向けコールセンターの存続状況と立地調整

Hua Yi (立命館大 ·院)：Learning ownership regulations through networks: Case studies on Japanese subsidiaries in China

都市社会地理研究グループ（教育福祉科学部 404）

水内俊雄（大阪市立大）：人文地理学界の持続的発展の可能性

本岡拓哉（立命館大・学振特別研究員）：日本に扔ける都市社会問題と地理学 